Article

\title{
Ecological Worldview among Urban Design Professionals
}

\author{
Marita Wallhagen ${ }^{1,2, *}$ and Peter Magnusson ${ }^{3,4}$ \\ 1 Department of Sustainable Development, Environmental Science and Engineering, KTH, \\ Royal Institute of Technology, Stockholm 10044, Sweden \\ 2 Department of Building, Energy and Environmental Engineering, University of Gävle, Gävle 80176, Sweden \\ 3 Centre for Research and Development, Uppsala University/Region Gävleborg, Gävle 80187, Sweden; \\ peter.magnusson@regiongavleborg.se \\ 4 Cardiology Research Unit, Department of Medicine, Karolinska Institutet, Stockholm 17176, Sweden \\ * Correspondence: marita.wallhagen@hig.se; Tel.: +46-706-009668
}

Academic Editors: Andy van den Dobbelsteen and Greg Keeffe

Received: 17 November 2016; Accepted: 22 March 2017; Published: 26 March 2017

\begin{abstract}
The built environment is responsible for a large proportion of the global use of energy, natural resources, and emissions. Architects and other urban design professionals are key actors in the building process whose behavior and decisions will influence these impacts. Because environmental attitudes are linked to pro-environmental behavior, this study aims to measure environmental worldview among urban design professionals involved in the architectural competition 'A New City Center for Kiruna'. The mean score registered for the New Environmental Paradigm (NEP) scale was 3.68 (standard deviation 0.51 ) and there were no significant differences with regard to age (mean 41.3 years) or gender (64.7\% males). The ecological worldview of the participants was similar to most other samples from diverse countries, but a lower score was reported in comparison to environmentalists. The score ranged from 2.53 to 4.67 which shows heterogeneity at an individual level. Thus, future efforts to improve environmental attitudes among urban design professionals are needed.
\end{abstract}

Keywords: architectural competition; ecological; environmental paradigm; pro-environmental behavior; urban design

\section{Introduction}

The built environment, including buildings and infrastructure, affects the environment throughout its life cycle-from extraction of natural resources to construction, use, and demolition. It constitutes a major part of the human use of energy and natural resources, and affects emissions to air, water, and land [1]. Today, buildings account for $40 \%$ of the global energy consumption [2] and buildings are constructed at a high rate [3]. In China alone, two billion square meters of commercial buildings are constructed per year [3]. An increase in urbanization, in combination with population growth, is predicted. Houses need to be planned, designed, and built for the six billion people expected to live in urban areas by 2045 [4].

Forecasts of global urbanization show that urban developments will have a large impact on the environment. The land-cover change that they create threatens biodiversity; they affect ecosystem productivity through loss of habitat, biomass, and carbon storage [5]. They will affect global croplands [6], use natural resources, and contribute to climate change.

In order to meet these demands of increased urbanization without depleting the environment, new and existing buildings need to meet high environmental standards and the decision makers influencing the built environment need to make more pro-environmental decisions. 
The importance of the built environment and its stakeholders has to be recognized if we are to meet the international agreement to decrease global warming [7]. Therefore, a more sustainable design of the built environment is crucial for both the environment and human health [8,9]. Moreover, it is feasible to reduce the environmental impact and even improve building quality without increasing costs [10]. The obstacles to more environmental and sustainable buildings and neighborhoods are not due to technological or economic limitations, but to social and psychological aspects [11].

A group of stakeholders with great potential to influence our environment are urban design professionals such as architects, landscape architects, urban planners, and urban designers who-even though they have different academic educations-are working with urban design. They are often presented as key actors in the complex planning and design process $[12,13]$ because they, in comparison to other groups, have the ability to influence how the built environment is planned, designed, and built. In Europe alone there are more than 565,000 architects [14]. As a consequence, they influence the environmental impact from the built environment and can contribute to diminishing the environmental impact. Thus, their views, attitudes, and values regarding environmental aspects are important to study.

Environmental values can influence pro-environmental behavior as ecological problems may stem from values, attitudes, and beliefs within our society $[15,16]$. The connection between values and behavior has been demonstrated [16]; some argue that engagement in pro-environmental behavior can be linked to emotional components of attitudes and, to some degree, also cognitive components (knowledge and beliefs) [17,18]. Studies have shown that internal processes can influence pro-environmental behavior [19], even though there are studies implying that the effect can be limited $[20,21]$ and 'the role of environmentalist predispositions can vary greatly with the behavior, the actor, and the context' [22]. Thus, external and internal factors should be considered as they both can be important psycho-social determinants for pro-environmental behavior [23]. Therefore, it is important to measure and interpret environmental attitudes, because doing so can provide insight into human interaction with Earth's resources. This knowledge may be used to form the basis for promoting more pro-environmental behavior, which is needed for long-term solutions to environmental challenges. However, few studies have been performed that measure internal factors, such as the environmental attitudes or pro-environmental behavior with regard to decision-making concerning built environment in general or specifically among urban design professionals. Attitudes and their relationship to pro-environmental behavior have typically been studied and found when it comes to personal habits in leisure time (non-working hours) such as waste management, recycling, travel mode choice, and pro-environmental buying [23].

The New Environmental Paradigm (NEP) scale was developed as a way to measure individuals' environmental/ecological worldviews [15]. It measures a conceptual paradigm or set of generalized beliefs that represent a concern for the environment [24]. This 12-item scale was later revised to a 15-item scale to provide a balanced set of pro- and anti-NEP items, avoid outmoded terminology, and include a wider range of facets of an ecological worldview. This includes the original three conceptually distinct but interrelated facets of: 'balance of nature' (beliefs that human activities impact the balance of nature), 'limits to growth' (beliefs that the Earth has limited resources), and 'human domination over nature' /'anti-anthropocentrism' (beliefs that human beings have the right to modify and control the natural environment), and the following facets: 'exemptionalism' (beliefs that human beings are not exempt from the constraints of nature) and 'ecocrisis' (beliefs that humans are causing detrimental harm to the physical environment) [25]. High scores on the NEP-scale have been linked to higher environmental awareness and more responsible environmental behavior [26] and the scale has been used in many surveys around the world $[27,28]$.

This-the importance of increased pro-environmental behavior among decision makers involved in the design, planning, and building of the built environment—constitutes a rationale for investigating ecological views among stakeholders in the building sector. With this as the starting point, the purpose 
of this study is to measure and interpret environmental attitudes among urban design professionals using the NEP-scale.

\section{Methods}

The international architectural competition 'A New City Centre for Kiruna' involved urban design professionals with different backgrounds in a large planning and design project regarding the development of the city of Kiruna (18,000 inhabitants) in northern Sweden. Because of the localization of mineral deposits, it was decided to move the city center. An architectural competition was organized which attracted numerous renowned architectural firms with a potential interest in the sustainability goals of the competition to take part. The Kiruna municipality selected 10 of the 54 teams in the pre-qualification phase (Appendix A). The selected teams were given the same instructions, maps, financial remuneration, and time constraints. This unique project above the polar circle required 'a sustainable model city' according to the competition program [29], but the brief had no quantitative sustainability criteria. The competition brief included goals such as:

" - to show a vision for the Kiruna of tomorrow. The watchwords of that vision must be sustainability, attractiveness and identity. The vision must affirm growth and new, robust patterns of living.

- to describe a strategy and a basic sustainable structure for accomplishing the urban transformation eastwards in a dynamic, quality-creating process, in which the new and the pre-existing will form a holistic entity and will function throughout the transformation process.

- to suggest ways of shaping a sustainable, distinctive and pleasant city centre in the east, within a holistic structure encompassing the entire city." [29]

The jury and the persons involved in the design of the competition proposals in the ten selected teams comprised the cohort for this study. A total of 149 participants were identified for inclusion in the study: 15 participants in the jury group, (eight jury members, seven jury advisors) and 134 competitors.

\subsection{Data Collection}

A web questionnaire in English (Appendix B), using the survey tool 'Survey Monkey' [30], was emailed to all participants, followed by three mail reminders and phone contact, between June and October 2013. Previously, results on usage of environmental assessment tools have been reported from this cohort [31]. In addition, the NEP-scale connected to the survey [25,32] was included and is presented in this paper. A cover letter provided information about the purpose of the study, voluntary participation, and handling of confidential data.

\subsection{Statistical Analyses}

The ordinal data of the five point Likert scale with responses from strongly disagree to strongly agree was assigned from one to five and reversed for every second question, with the implication that the higher number the more pro-NEP indicating a more pro-environmental attitude. Data was imported into SPSS version 22 (IBM, Armonk, NY, USA) and Excel 2010 (Microsoft Corporation, Redmond, WA, USA) and described as numbers, percentages, means, standard deviations (SD), medians, and percentiles where appropriate. A $t$-test was used to compare means between groups. A two-sided $p$-value $<0.05$ was considered significant.

\section{Results}

The NEP questions were completed by 68 urban design professionals (response rate $46 \%$ ). All participants worked in Europe, mainly Sweden and neighboring countries, and the majority were male $(64.7 \%)$. Architects together with landscape architects constituted $72.0 \%$ of the urban design professionals and accordingly the vast majority had a university education of five years or 
more. Mean age was similar among males and females, 41.3 years (SD 10.1) and 41.5 years (SD 10.2), respectively $(p=0.964)$. The characteristics of the cohort are summarized in Table 1.

The mean NEP-score was 3.68 (SD 0.51). It ranged from 2.53 to 4.67 and the 25, 50, and 75 percentiles were $3.28,3.70$, and 4.07 , respectively (Table 2 ).

Table 1. Characteristics of participants in the survey (Characteristics of participants $n=68$ ).

\begin{tabular}{ll}
\hline Characteristics & $\mathbf{n ~ ( \% )}$ \\
\hline Age & \\
\hline 20-30 years & $7(10.3)$ \\
31-40 years & $27(39.7)$ \\
41-50 years & $22(30.9)$ \\
51-60 years & $10(14.7)$ \\
61-70 years & $3(4.4)$ \\
\hline Gender & $\mathrm{n}(\%)$ \\
\hline Male & $44(64.7)$ \\
Female & $24(35.3)$ \\
\hline Working country & \\
\hline Sweden & $42(61.8)$ \\
Denmark & $8(11.8)$ \\
Germany & $3(4.4)$ \\
Norway & $3(4.4)$ \\
The United Kingdom & $3(4.4)$ \\
Spain & $2(2.9)$ \\
Switzerland & $2(2.9)$ \\
The Netherlands & $2(2.9)$ \\
Other country & $3(4.4)$ \\
\hline Profession & \\
\hline Architect & $36(52.9)$ \\
Landscape architect & $13(19.1)$ \\
Urban planner & $6(8.8)$ \\
Engineer & $4(5.9)$ \\
Other * & $9(13.2)$ \\
\hline Education & \\
\hline University 3 years & $2(2.9)$ \\
University 4 years & $5(7.4)$ \\
University $\geq 5$ years & $54(79.4)$ \\
Doctoral degree & $7(10.3)$ \\
\hline Role in the project & \\
\hline Competitor & $58(85.3)$ \\
Jury member & $4(5.9)$ \\
Jury advisor & $6(4.4)$ \\
\hline
\end{tabular}

* Consultant, Cultural heritage expert, Cultural planner, Ecologist, Economist, Lighting designer, Municipal administrator, Planning and development, Social planner, and a Transport economist. 
Table 2. New Environmental Paradigm (NEP) scale among urban design professionals $(n=68)$ (Statements about the Relationship between Humans and the Environment).

\begin{tabular}{|c|c|c|c|c|c|c|c|c|c|c|c|c|}
\hline \multirow{2}{*}{$\begin{array}{l}\text { Do you Agree or Disagree that }{ }^{\text {a: }} \\
\text { 1. We are approaching the limit of the number of people the Earth can support. }\end{array}$} & \multicolumn{2}{|c|}{$\begin{array}{l}\text { Strongly } \\
\text { Agree }\end{array}$} & \multicolumn{2}{|c|}{$\begin{array}{l}\text { Mildly } \\
\text { Agree }\end{array}$} & \multicolumn{2}{|c|}{ Unsure } & \multicolumn{2}{|c|}{$\begin{array}{c}\text { Mildly } \\
\text { Disagree }\end{array}$} & \multicolumn{2}{|c|}{$\begin{array}{l}\text { Strongly } \\
\text { Disagree }\end{array}$} & \multicolumn{2}{|c|}{ Mean SD } \\
\hline & 10 & $15 \%$ & 15 & $22 \%$ & 22 & $32 \%$ & 18 & $26 \%$ & 3 & $4 \%$ & 3.16 & 1.11 \\
\hline 2. Humans have the right to modify the natural environment to suit their needs. & 8 & $12 \%$ & 17 & $25 \%$ & 10 & $15 \%$ & 19 & $28 \%$ & 14 & $20 \%$ & 3.21 & 1.34 \\
\hline 3. When humans interfere with nature it often produces disastrous consequences. & 11 & $16 \%$ & 26 & $38 \%$ & 8 & $12 \%$ & 17 & $25 \%$ & 6 & $9 \%$ & 3.28 & 1.26 \\
\hline 4. Human ingenuity will insure that we do NOT make the Earth unlivable. & 1 & $1 \%$ & 17 & $25 \%$ & 33 & $48 \%$ & 12 & $17 \%$ & 5 & $7 \%$ & 3.04 & 0.89 \\
\hline 5. Humans are severely abusing the environment. & 31 & $46 \%$ & 30 & $44 \%$ & 3 & $4 \%$ & 2 & $3 \%$ & 2 & $3 \%$ & 4.26 & 0.91 \\
\hline 6. The Earth has plenty of natural resources if we just learn how to develop them. & 16 & $24 \%$ & 28 & $41 \%$ & 7 & $10 \%$ & 9 & $13 \%$ & 8 & $12 \%$ & 2.49 & 1.31 \\
\hline 7. Plants and animals have as much right as humans to exist. & 32 & $47 \%$ & 22 & $32 \%$ & 6 & $9 \%$ & 8 & $12 \%$ & 0 & $0 \%$ & 4.15 & 1.01 \\
\hline 8. The balance of nature is strong enough to cope with the impacts of modern industrial nations. & 0 & $0 \%$ & 3 & $4 \%$ & 17 & $25 \%$ & 22 & $32 \%$ & 26 & $38 \%$ & 4.04 & 0.90 \\
\hline 9. Despite our special abilities humans are still subject to the laws of nature. & 29 & $43 \%$ & 28 & $41 \%$ & 8 & $12 \%$ & 2 & $3 \%$ & 1 & $1 \%$ & 4.21 & 0.87 \\
\hline 10. The so-called 'ecological crisis' facing humankind has been greatly exaggerated. & 0 & $0 \%$ & 4 & $6 \%$ & 12 & $18 \%$ & 25 & $37 \%$ & 27 & $39 \%$ & 4.10 & 0.90 \\
\hline 11. The Earth is like a spaceship with very limited room and resources. & 20 & $29 \%$ & 21 & $31 \%$ & 12 & $17 \%$ & 10 & $15 \%$ & 5 & $7 \%$ & 3.60 & 1.26 \\
\hline 12. Humans were meant to rule over the rest of nature. & 0 & $0 \%$ & 2 & $3 \%$ & 10 & $15 \%$ & 10 & $15 \%$ & 46 & $67 \%$ & 4.47 & 0.85 \\
\hline 13. The balance of nature is very delicate and easily upset. & 23 & $34 \%$ & 23 & $34 \%$ & 13 & $19 \%$ & 9 & $13 \%$ & 0 & $0 \%$ & 3.88 & 1.03 \\
\hline 14. Humans will eventually learn enough about how nature works to be able to control it. & 2 & $3 \%$ & 12 & $18 \%$ & 27 & $40 \%$ & 20 & $29 \%$ & 7 & $10 \%$ & 3.26 & 0.97 \\
\hline 15. If things continue on their present course, we will soon experience a major ecological catastrophe. & 23 & $34 \%$ & 28 & $41 \%$ & 16 & $23 \%$ & 1 & $1 \%$ & 0 & $0 \%$ & 4.07 & 0.80 \\
\hline Total: & 206 & $20 \%$ & 276 & $27 \%$ & 204 & $20 \%$ & 184 & $18 \%$ & 150 & $15 \%$ & 3.68 & 1.03 \\
\hline
\end{tabular}

a Ouestion wording: 'Listed below are statements about the relationship between humans and the environment. For each one, please indicate whether you agree or disagree with it:' Agreement with the odd numbered items and disagreement with the even numbered items indicate pro-NEP responses; Scale for odd numbered questions: Strongly disagree = 1, Mildly disagree $=2$, Unsure $=3$, Mildly agree $=4$, Strongly agree $=5$; reverted scale for even numbered questions. SD, Standard Deviation. 
The mean score was similar with regard to gender $(p=0.528)$ and age dichotomized strata $(p=0.850)$. A multiple regression analysis of age, gender, and the interaction term between the two showed no statistical significance ( $p$-value $0.740,0.981$, and 0.892 , respectively). An analysis of the subgroups on the basis of their professions showed similar mean scores: architects 3.61 (SD 0.46; $n=36$ ), engineers 3.80 (SD $0.56 ; n=4$ ), landscape architect 3.64 (SD $0.45 ; n=13$ ), urban planners 3.86 (SD 0.42; $n=6$ ), and others 3.89 (SD 0.77; $n=9$ ). T-test showed no significant difference between architects and the remaining sample $(p=0.193)$ (architects $3.61 ;$ SD $0.46 ; n=36$ vs. other professionals 3.77 ; SD $0.55 ; n=32$ ).

The largest spreads, expressed as SD, were among question 2 (SD 1.34), question 6 (SD 1.31), question 3 (SD 1.26), and question 11 (SD 1.26) while the smallest were among question 15 (SD 0.80 ), question 12 (SD 0.85), question 9 (SD 0.87), and question 4 (SD 0.89). For two questions, 4 and 14, the answer 'unsure' was chosen by $48 \%$ and $40 \%$ respectively of the respondents. The most pro-NEP response, where participants strongly agreed or strongly disagreed, was question 12 (mean 4.47; 67\% strongly disagreed). The least pro-NEP response was given in questions 6 (mean 2.49).

For the single question 7 'Plants and animals have as much right as humans to exist', which is the question which best discriminates between the measure of ecocentrism and anthropocentrism [33], the participants scored high, mean 4.15 (SD 1.01), where $47 \%$ strongly agreed and $32 \%$ agreed. This can indicate that the participants' values recognize an intrinsic value for plants and animals.

The hypothesized facets of NEP are presented in Table 3 with the highest score for the facet 'the risk of an ecocrisis', followed by 'human domination over nature' and the lowest score for 'limits to growth'.

Table 3. New Environmental Paradigm (NEP) Scale results among urban design professionals $(n=68)$ grouped into five hypothesized facets (Question Grouped into Five Hypothesized Facets).

\begin{tabular}{|c|c|c|c|c|c|c|c|c|c|c|c|}
\hline \multirow{2}{*}{$\begin{array}{l}\text { Hypothesized Facets } \\
\text { Human domination over nature (2. 7. 12.) }\end{array}$} & \multicolumn{2}{|c|}{$\begin{array}{c}\text { Strongly } \\
\text { Agree }\end{array}$} & \multicolumn{2}{|c|}{$\begin{array}{l}\text { Mildly } \\
\text { Agree }\end{array}$} & \multicolumn{2}{|c|}{ Unsure } & \multicolumn{2}{|c|}{$\begin{array}{c}\text { Mildly } \\
\text { Disagree }\end{array}$} & \multicolumn{2}{|c|}{$\begin{array}{l}\text { Strongly } \\
\text { Disagree }\end{array}$} & \multirow{2}{*}{$\begin{array}{r}\text { Mean } \\
3.94\end{array}$} \\
\hline & 40 & $20 \%$ & 41 & $20 \%$ & 26 & $13 \%$ & 37 & $18 \%$ & 60 & $29 \%$ & \\
\hline Human exemptionalism (4. 9. 14.) & 32 & $16 \%$ & 57 & $28 \%$ & 68 & $33 \%$ & 34 & $17 \%$ & 13 & $6 \%$ & 3.50 \\
\hline Balance of nature (3. 8. 13.) & 34 & $17 \%$ & 52 & $25 \%$ & 38 & $19 \%$ & 48 & $24 \%$ & 32 & $16 \%$ & 3.74 \\
\hline The risk of an ecocrisis (5. 10. 15.) & 54 & $26 \%$ & 62 & $30 \%$ & 31 & $15 \%$ & 28 & $14 \%$ & 29 & $14 \%$ & 4.15 \\
\hline Limits to growth (1. 6. 11.) & 46 & $23 \%$ & 64 & $31 \%$ & 41 & $20 \%$ & 37 & $18 \%$ & 16 & $8 \%$ & 3.08 \\
\hline
\end{tabular}

The numbers in parenthesis refer to the question included in the facet.

\section{Discussion}

Urban design professionals, using the NEP-scale, report a heterogeneous estimate of ecological worldview between individuals. The NEP-scores ranged from the relatively low (2.67) to very high (4.67) suggesting a spread which may account for differences in action with regard to decision-making in their professional role. This implies that one should bear in mind the variations on an individual level when considering the mean score of 3.68. The statistical spread, expressed as standard deviation, is comparable to most other samples summarized in the meta-analysis by Hawcroft and Milfont [28].

This mean value is interesting to compare to other samples. In order to provide a fair comparison between the numerous samples this comparison should be limited to studies using the 15-item revised NEP-scale, because proportionality between scales cannot be assumed. Most other studies refer to convenience samples such as students, but there are also studies with other sample groups. However, it is often not clear what kind of education and what educational level these samples comprise. Typically, they have a younger age distribution and a higher percentage of females. Several studies report mean values similar to our cross-sectional study in urban design professionals (mean 3.68, mean age 39 years, 65\% males). Casey and Scott [34] reported a mean of 3.69 among 292 Australians, mean age 36 years, with a minority of males (36\%); Castro and Lima [35] showed a mean score of 3.72 among Portuguese with a mean aged 40 years and 30\% males. A large Swedish sample of 922 representatives (mean age 48 years) and $49 \%$ men reported a mean of 3.67 [36]. A similar mean (3.65) was reported in a 
US representative sample of 206 individuals [37]. Two Canadian cohorts with 457 (mean age 45 years) and 178 individuals, respectively, both reported a mean of 3.67 [38,39].

Studies of students, whose mean aged was 21-24 years, with a majority of females reported the following sample size and mean NEP-score: UK ( $n=200$; mean 3.88), Brazil ( $n=60 ; 3.73)$, Canada $(n=96 ; 3.83)$, Spain $(n=104 ; 3.83)$, the US $(n=245 ; 3.67)$, and various South America samples ( $n=65-224 ; 3.69-4.11$ ) [40-44]. Notably a German student cohort ( $75 \%$ females, mean age 24 years) reported a score higher than other student groups, 4.02 [45]. A US cohort of 206 representatives showed a mean score of 3.65 [46]. Thus, our cohort of urban professionals reported similar means as most of the mentioned samples despite differences in age and gender distribution. However, NEP-scores have also been studied on the broadly defined group 'environmentalist', who are typically members of an environmental organization. As expected, these persons have high NEP-scores. Olli et al. [47] reported a Norwegian sample of 2000 environmentalists who had a mean-score of 4.09, while another representative sample $(n=3686)$ from the same authors reported 3.69. This was confirmed by UK findings of a NEP-score of 4.22 among environmentalists [48].

The lower mean score among urban professionals compared to environmentalists suggests a potential for improvement. Probably, urban professionals with a more positive ecological view would imply a more environmental friendly approach in their building projects. From this cross-sectional study we are not able to conclude if ecological views change over time and what factors may influence individuals towards making a more positive change. There are consistent findings that environment-related attitudes are acquired during childhood $[49,50]$ and that they tend to persist unchanged throughout life [51] but can be influenced [52]. Moreover, even if urban professionals would have higher ecological values, they are part of a system with economic constrains and other limitations and they are affected by the impact of other stakeholders. This might constrain them from designing more environmentally built environments. However, there are projects in which higher environmental targets have been met and negative environmental impacts decreased, despite the same cultural context, regulation, and market $[53,54]$. Therefore, it is clear that more environmentally built environments can be designed regardless of economical, legal, or social constraints. The change to a more ecological view after childhood and engagement in pro-environmental behavior (e.g., environmental decision-making) probably need to include legislation and compensation in addition to identity campaigning [52] or educational efforts [55], even though educational efforts might give marginal effects on behavior change [56]. It has also been recognized that pro-environmental behavior can be obtained when individuals have non-environmental goals such as saving money or improving their health [57] as long as it correlates with positive environmental impacts. The potential link between the NEP-scores and the social context, such as the environmental attitude among the respondents' colleagues or employers, was not considered as crucial because responses on other questions in the questionnaire did not point in that direction. When asked about what aspects that could have improved the competition proposals from an environmental point of view the following aspects scored the lowest among all 18 aspects: 'a more environmentally friendly attitude among competition team members' (yes, $n=8$; maybe, $n=26$; no, $n=38$ ) and 'a more environmentally friendly attitude at your company' (yes, $n=6$; maybe, $n=23 ;$ no, $n=39$ ) [31].

Urban professionals show no gender difference with regard to mean NEP-score. Not many other studies have studied gender differences and few have found any significant differences. However, female students held stronger biospheric-altruistic values than their male counterparts [24]. Deng et al [38] studied Canadians students and found females to be more supportive of biosphere, altruistic values, and anti-anthropocentrism. American studies on blue-collar workers, using a 12-item NEP-scale, seem to indicate a lower NEP-score. Not only is the educational level, expressed as years at university, a likely predictor of higher NEP-score, but it may also be influenced by the kind of education. This should be addressed further using diverse samples and preferably extended to action research on urban professionals. An educational intervention on post-graduate urban professionals would be beneficial in order to provide tools for future improvements of ecological view. 
Cultural background may influence ecological worldview. A comparison showed higher NEP-score among Japanese samples than Americans across the categories of: representative sample, white-collar workers, and environmentalists. The complex associations underlying NEP-score are likely to be influenced by socio-economic factors, education, cultural background, and on an individual level, possibly personal traits [26].

The five hypothesized facets have been suggested to reflect different conceptually distinct but interrelated parts of an ecological view. The facet with the highest mean NEP-score was 'The risk of an ecocrisis' (mean 4.15). Interestingly, 90\% agreed (strongly or mildly) to question 5, 'Humans are severely abusing the environment'; still $6 \%$ of our sample mildly agreed to the statement that the 'ecological crisis' is exaggerated. The facet with the lowest score was 'Limits to growth' (mean 3.08). Here, question 6, 'The Earth has plenty of natural resources if we just learn how to develop them', was the question with the lowest NEP-score (mean 2.49). For the other two questions included in that facet, question 1 (mean 3.16) and 11 (mean 3.60) (Table 2), the scores were also low. Based on these results, it seems like the respondents recognize the risk of an ecocrisis, that humans are abusing the environment, and continuing on this present course can lead to a major catastrophe-meaning that many urban design professionals are aware of the existing environmental problems. On the other hand, the facet 'Limits to growth' corresponding to questions about population growth and natural resources had the lowest scores, and thus was not considered important by several respondents. It is not possible to know if this has any connection to the fact that the urban design professionals are working with growth, change, technological interventions, things which for them are valuable. This tendency is further recognized as the facet with the second lowest mean score was 'Human exemptionalism' expressing beliefs that human beings are not exempt from the constraints of nature. Here, in question $14,21 \%$ agreed (strongly or mildly) that humans will learn enough about nature to be able to control it, and in question 4, 'Human ingenuity will insure that we do NOT make the Earth unlivable', 26\% agreed (strongly or mildly). Question 4 also had the second lowest mean score of all questions (mean 3.04) and had the highest number of scores in the middle of the scale. Here the participants were the most 'unsure' and the standard deviation was low. Thus, there might have been a more positivistic and technopositivistic view among the participants in our study than among the general public.

Moreover, this view is combined with a high scoring of the right to exist of plants and animals (question 7, mean 4.15 (SD 1.01), where $47 \%$ strongly agreed and $32 \%$ mildly agreed). This may be interpreted as the participants would like to make it possible to combine nature conservation with urban planning and built environments.

Furthermore, low NEP-scores on some questions highlight that some respondents express a non-ecological worldview to some extent. This underscores the view that white-collar workers, like urban professionals, can express negative environmental attitudes. If these attitudes influence pro-environmental behavior it is likely that it can have a large impact on the environmental performance of the urban environments these professionals design.

\section{Conclusions}

This first study on ecological view among urban professionals, using the NEP-score, reports a mean value of 3.68. It gives insight into their overall ecological view which is consistent with most other study samples (students and representatives) from diverse countries, but shows a lower score than for environmentalists. Within the study of urban professionals, age, gender, and profession did not correlate with ecological view. Future research may study the correlation between environmental attitudes and pro-environmental behavior expressed as environmental design among urban design professionals. It could also concern potential influence of interventions affecting urban design professionals' environmental attitudes and include long-term follow-ups.

Acknowledgments: We appreciate the support from University of Gävle for funding parts of the research presented here. 
Author Contributions: Marita Wallhagen conceived and designed the survey and performed the experiments; Marita Wallhagen and Peter Magnusson analyzed the data, made statistical data analysis, and wrote the paper.

Conflicts of Interest: The authors declare no conflict of interest. The founding sponsors had no role in the design of the study; in the collection, analyses, or interpretation of data; in the writing of the manuscript, and in the decision to publish the results.

\section{Appendix A. Teams and Companies Involved in the Competition}

- Designteam AIM (Helsingborg) and Onix Sweden AB (Helsingborg) with advisors/consultants Noema Culture \& Place Mapping (London), Atkins (Malmö) and Farawaysoclose/Apokalyps Labotek (Malmö)

- Bjarke Ingels Group (Copenhagen), Spacescape (Stockholm), Testbedstudio (Stockholm), Topotek 1\& Man Made Land (Berlin) and Resource Vision (Stockholm)

- $\quad$ BSK Arkitekter AB (Stockholm), MVRDV (Rotterdam) and Grontmij in Sweden AB (Stockholm)

- $\quad$ COBE Aps (Copenhagen) with advisors Kragh \& Berglund (Copenhagen and Stockholm), Moe \& Brödsgård (Rödovre), Yngve Andrén Konsult AB (Stockholm) and Boris Broman Jensen (Århus)

- Ecosistema Urbana (Madrid), Arkitekt Kristine Jensens Tegnestue (Århus), 700N arkitektur AS (Tromsö), Ljusarkitektur (Stockholm) and Atkins (Stockholm)

- $\quad$ KCAP Architect \& Planners (Rotterdam) and CaseStudio (Göteborg)

- Norconsult Byplan (Sandvika), Norconsult landskapsarkitekt (Sandvika), Fantastic Norway (Oslo) and 0047 International AS (Oslo)

- Tham och Videgård Arkitekter (Stockholm), Territorial Agency (London) and a_zero environmental architects (London)

- Tovatt Architects \& Planners (Stockholm), Atelier Dreiseitl (Üeberlingen), Urban Think Tank Architects LLC (Zürich) and Wenanders (Stockholm)

- White arkitekter AB (Stockholm), Ghilardi + Hellsten (Oslo), Spacescape (Stockholm), Vectura Consulting AB (Solna) and Evidens BLW AB (Stockholm)

\section{Appendix B. Questions Asked in the Questionnaire Used in This Study}

Please select the one answer that best applies.

1. In which country do you primarily work?

Denmark

Ireland

Norway

Switzerland

Spain

Sweden

The Netherlands

United Kingdom

Other (please specify)

2. Are you male or female?

Male

Female

3. When were you born?

A list of years (1930-1990) 
4. What is your main profession?

\author{
Architect \\ Designer \\ Engineer \\ Landscape architect \\ Politician \\ Urban planner \\ Other (please specify)
}

\title{
5. What formal education do you have?
}

High school graduate or less

University 1 year

University 2 years

University 3 years

University 4 years

University 5 years or more

$P h D$

6. What role did you have in the Kiruna project?

Competitor

Jury member

Jury advisor

If the answer to question 6 is competitor, please answer questions 7, 8 and 9:

7. As a competitor, what was your main responsibility?

Administration

Design

Business executive or CEO

Leading the group

Production of drawings/blue prints

Production of illustrations

Production of text

Other (please specify)

8. How many employees work at your company?

1-4 employees

$5-9$ employees

10-29 employees

30-49 employees

50-100 employees

101-200 employees

201 or more employees

9. How many people were involved in your competition team in the Kiruna competition?

$$
\begin{aligned}
& \text { 1-4 people } \\
& \text { 5-9 people } \\
& \text { 10-25 people } \\
& \text { 30-49 people } \\
& 50 \text { or more people }
\end{aligned}
$$

Note: The questions 10-23 in the questionnaire are purposely omitted here. Those questions were about the respondents use of environmental assessment tools for buildings and neighborhoods and their view on a number of environmental aspects. These questions are omitted from this appendix because this paper does not explore those issues. 
24. Listed below are statements about the relationship between humans and the environment.

Do you agree or disagree that: (Strongly agree - Mildly agree - Unsure - Mildly disagree - Strongly disagree)

1. We are approaching the limit of the number of people the Earth can support.

2. Humans have the right to modify the natural environment to suit their needs.

3. When humans interfere with nature it often produces disastrous consequences.

4. Human ingenuity will insure that we do NOT make the Earth unlivable.

5. Humans are severely abusing the environment.

6. The Earth has plenty of natural resources if we just learn how to develop them.

7. Plants and animals have as much right as humans to exist.

8. The balance of nature is strong enough to cope with the impacts of modern industrial nations.

9. Despite our special abilities humans are still subject to the laws of nature.

10. The so-called 'ecological crisis' facing humankind has been greatly exaggerated.

11. The Earth is like a spaceship with very limited room and resources.

12. Humans were meant to rule over the rest of nature.

13. The balance of nature is very delicate and easily upset.

14. Humans will eventually learn enough about how nature works to be able to control it.

15. If things continue on their present course, we will soon experience a major ecological catastrophe.

\section{References}

1. Khasreen, M.; Banfill, P.F.; Menzies, G. Life-cycle assessment and the environmental impact of buildings: A review. Sustainability 2009, 1, 674. [CrossRef]

2. Omer, A.M. Energy, environment and sustainable development. Renew. Sustain. Energy Rev. 2008, 12, 2265-2300. [CrossRef]

3. Diamond, R.; Ye, Q.; Feng, W.; Yan, T.; Mao, H.; Li, Y.; Guo, Y.; Wang, J. Sustainable building in china-A green leap forward? Buildings 2013, 3, 639. [CrossRef]

4. United Nations. World's Population Increasingly Urban With More Than Half Living in Urban Areas. Available online: http://www.un.org/en/development/desa/news/population/world-urbanizationprospects-2014.html (accessed on 22 March 2017).

5. Seto, K.C.; Güneralp, B.; Hutyra, L.R. Global forecasts of urban expansion to 2030 and direct impacts on biodiversity and carbon pools. Proc. Natl. Acad. Sci. USA 2012, 109, 16083-16088. [CrossRef] [PubMed]

6. D'Amour, C.B.; Reitsma, F.; Baiocchi, G.; Barthel, S.; Güneralp, B.; Erb, K.-H.; Haberl, H.; Creutzig, F.; Seto, K.C. Future urban land expansion and implications for global croplands. Proc. Natl. Acad. Sci. USA 2016. [CrossRef]

7. Rogelj, J.; den Elzen, M.; Höhne, N.; Fransen, T.; Fekete, H.; Winkler, H.; Schaeffer, R.; Sha, F.; Riahi, K.; Meinshausen, M. Paris agreement climate proposals need a boost to keep warming well below $2{ }^{\circ} \mathrm{C}$. Nature 2016, 534, 631-639. [CrossRef] [PubMed]

8. Azhar, S.; Carlton, W.A.; Olsen, D.; Ahmad, I. Building information modeling for sustainable design and leed ${ }^{\circledR}$ rating analysis. Autom. Constr. 2011, 20, 217-224. [CrossRef]

9. McMichael, A.J. Globalization, climate change, and human health. New Engl. J. Med. 2013, 368, 1335-1343. [CrossRef] [PubMed]

10. Kats, G.; Alevantis, L.; Berman, A.; Mills, E.; Perlman, J. The Costs and Financial Benefits of Green Buildings: A Report to California's Sustainable Building Task Force; The Sustainable Building Task Force and Capital E: USA, 2003. Available online: http:/ / evanmills.lbl.gov/pubs/pdf/green_buildings.pdf (accessed on 26 March 2017).

11. Hoffman, A.J.; Henn, R. Overcoming the social and psychological barriers to green building. Organ. Environ. 2008, 21, 390-419. [CrossRef]

12. Chen, B.; Pitts, A.; Ward, I. In Paper 132: Sustainability related educational programmes for sustainable housing design. In Proceedings of the plea 2008-25th Conference on Passive and Low Energy Architecture, Dublin, Ireland, 22-24 October 2008.

13. Elforgani, M.S.; Rahmat, I. An investigation of factors influencing design team attributes in green buildings. Am. J. Appl. Sci. 2010, 7, 976. [CrossRef] 
14. Mirza and Nacey Research. The Architectural Profession in Europe 2014-A Sector Study, The Architects Council of Europe; Mirza and Nacey Research: West Sussex, UK, 2015. Available online: http://www.ace-cae. eu/fileadmin/New_Upload/7._Publications /Sector_Study/2014/EN/2014_EN_FULL.pdf (accessed on 10 December 2016).

15. Dunlap, R.E.; Van Liere, K.D. The "new environmental paradigm". J. Environ. Educ. 1978, 9, 10-19. [CrossRef]

16. Disch, R. The Ecological Consciencevalues for Survival; Prentice Hall: Upper Saddle River, NJ, USA, 1970.

17. Hinds, J.; Sparks, P. Engaging with the natural environment: The role of affective connection and identity. J. Environ. Psychol. 2008, 28, 109-120. [CrossRef]

18. Cheng, J.C.-H.; Monroe, M.C. Connection to nature: Children's affective attitude toward nature. Environ. Behav. 2012, 44, 31-49. [CrossRef]

19. Clark, C.F.; Kotchen, M.J.; Moore, M.R. Internal and external influences on pro-environmental behavior: Participation in a green electricity program. J. Environ. Psychol. 2003, 23, 237-246. [CrossRef]

20. Hines, J.M.; Hungerford, H.R.; Tomera, A.N. Analysis and Synthesis of Research on Responsible Environmental Behavior: A Meta-Analysis. J. Environ. Educ. 1987, 18, 1-8. [CrossRef]

21. Bamberg, S. How does environmental concern influence specific environmentally related behaviors? A new answer to an old question. J. Environ. Psychol. 2003, 23, 21-32. [CrossRef]

22. Stern, P.C. New Environmental Theories: Toward a Coherent Theory of Environmentally Significant Behavior. J. Soc. Issues 2000, 56, 407-424. [CrossRef]

23. Bamberg, S.; Möser, G. Twenty years after Hines, Hungerford, and Tomera: A new meta-analysis of psycho-social determinants of pro-environmental behaviour. J. Environ. Psychol. 2007, 27, 14-25. [CrossRef]

24. Stern, P.C.; Dietz, T.; Guagnano, G.A. The New Ecological Paradigm in Social-Psychological Context. Environ. Behav. 1995, 27, 723-743. [CrossRef]

25. Dunlap, R.E.; Van Liere, K.D.; Mertig, A.G.; Jones, R.E. Measuring endorsement of the new ecological paradigm: A revised nep scale. J. Soc. Issues 2000, 56, 425-442. [CrossRef]

26. Wiidegren, Ö. The new environmental paradigm and personal norms. Environ. Behav. 1998, 30, 75-100. [CrossRef]

27. Dunlap, R.E. The New Environmental Paradigm Scale: From Marginality to Worldwide Use. J. Environ. Educ. 2008, 40, 3-18. [CrossRef]

28. Hawcroft, L.J.; Milfont, T.L. The use (and abuse) of the new environmental paradigm scale over the last 30 years: A meta-analysis. J. Environ. Psychol. 2010, 30, 143-158. [CrossRef]

29. Kiruna Kommun (Kiruna Municipality). Program för Arkitekttävling- ny Stadskärna i Kiruna (Architecture Competition Programme-A New City Centre for Kiruna); Kiruna Kommun (Kiruna municipality): Kiruna, Sweden, 2012. (In Swedish) Available online: http://www.kiruna.se/PageFiles/5559/tavlingsprogram\% 20stadsbyggnadst \%C3\%A4vlingen.pdf?epslanguage=sv (accessed on 26 March 2017).

30. SurveyMonkey Inc. Surveymonkey, SurveyMonkey Inc.: Paolo Alto, CA, USA, 2015.

31. Wallhagen, M.; Malmqvist, T.; Eriksson, O. Professionals' knowledge and use of environmental assessment in an architectural competition. Build. Res. Inf. 2016, 1-17. [CrossRef]

32. Harraway, J.; Broughton-Ansin, F.; Deaker, L.; Jowett, T.; Shephard, K. Exploring the use of the revised new ecological paradigm scale (nep) to monitor the development of students' ecological worldviews. J. Environ. Educ. 2012, 43, 177-191. [CrossRef]

33. Lundmark, C. The new ecological paradigm revisited: Anchoring the nep scale in environmental ethics. Environ. Educ. Res. 2007, 13, 329-347. [CrossRef]

34. Casey, P.J.; Scott, K. Environmental concern and behaviour in an australian sample within an ecocentric anthropocentric framework. Aust. J. Psychol. 2006, 58, 57-67. [CrossRef]

35. Castro, P.; Lima, M.L. Old and new ideas about the environment and science: An exploratory study. Environ. Behav. 2001, 33, 400-423. [CrossRef]

36. Eriksson, L.; Garvill, J.; Nordlund, A.M. Acceptability of travel demand management measures: The importance of problem awareness, personal norm, freedom, and fairness. J. Environ. Psychol. 2006, 26, 15-26. [CrossRef]

37. Kotchen, M.J.; Reiling, S.D. Environmental attitudes, motivations, and contingent valuation of nonuse values: A case study involving endangered species. Ecol. Econ. 2000, 32, 93-107. [CrossRef] 
38. McFarlane, B.L.; Stumpf-Allen, R.C.G.; Watson, D.O. Public perceptions of natural disturbance in canada's national parks: The case of the mountain pine beetle (dendroctonus ponderosae hopkins). Biol. Conserv. 2006, 130, 340-348. [CrossRef]

39. Deng, J.; Walker, G.J.; Swinnerton, G. A comparison of environmental values and attitudes between chinese in canada and anglo-canadians. Environ. Behav. 2006, 38, 22-47. [CrossRef]

40. Cooper, P.; Poe, G.L.; Bateman, I.J. The structure of motivation for contingent values: A case study of lake water quality improvement. Ecol. Econ. 2004, 50, 69-82. [CrossRef]

41. Vikan, A.; Camino, C.; Biaggio, A.; Nordvik, H. Endorsement of the new ecological paradigm: A comparison of two brazilian samples and one norwegian sample. Environ. Behav. 2007, 39, 217-228. [CrossRef]

42. Schultz, P.W.; Zelezny, L. Values as predictors of environmental attitudes: Evidence for consistency across 14 countries. J. Environ. Psychol. 1999, 19, 255-265. [CrossRef]

43. Schultz, P.W.; Unipan, J.B.; Gamba, R.J. Acculturation and ecological worldview among latino americans. J. Environ. Educ. 2000, 31, 22-27. [CrossRef]

44. Zelezny, L.C.; Chua, P.-P.; Aldrich, C. New ways of thinking about environmentalism: Elaborating on gender differences in environmentalism. J. Soc. Issues 2000, 56, 443-457. [CrossRef]

45. Schultz, P.W.; Gouveia, V.V.; Cameron, L.D.; Tankha, G.; Schmuck, P.; Franěk, M. Values and their relationship to environmental concern and conservation behavior. J. Cross-Cult. Psychol. 2005, 36, 457-475. [CrossRef]

46. Kotchen, M.J.; Moore, M.R. Private provision of environmental public goods: Household participation in green-electricity programs. J. Environ. Econ. Manag. 2007, 53, 1-16. [CrossRef]

47. Olli, E.; Grendstad, G.; Wollebaek, D. Correlates of environmental behaviors: Bringing back social context. Environ. Behav. 2001, 33, 181-208. [CrossRef]

48. Pahl, S.; Harris, P.R.; Todd, H.A.; Rutter, D.R. Comparative optimism for environmental risks. J. Environ. Psychol. 2005, 25, 1-11. [CrossRef]

49. Nancy, M.W.; Kristi, S.L. Nature and the Life Course: Pathways from Childhood Nature Experiences to Adult Environmentalism. Child. Youth Environ. 2006, 16, 1-24.

50. Kahn, P.H.; Kellert, S.R. Children and Nature: Psychological, Sociocultural, and Evolutionary Investigations; MIT Press: Cambridge, MA, USA, 2002.

51. Kaiser, F.G.; Brügger, A.; Hartig, T.; Bogner, F.X.; Gutscher, H. Appreciation of nature and appreciation of environmental protection: How stable are these attitudes and which comes first? Rev. Eur. Psychol. Appl./Eur. Rev. Appl. Psychol. 2014, 64, 269-277. [CrossRef]

52. Gatersleben, B.; Murtagh, N.; Abrahamse, W. Values, identity and pro-environmental behaviour. Contemp. Soc. Sci. 2014, 9, 374-392. [CrossRef]

53. Cidell, J. Building Green: The Emerging Geography of LEED-Certified Buildings and Professionals. Prof. Geogr. 2009, 61, 200-215. [CrossRef]

54. Cole, R.J.; Jose Valdebenito, M. The importation of building environmental certification systems: international usages of BREEAM and LEED. Build. Res. Inf. 2013, 41, 662-676. [CrossRef]

55. Turaga, R.M.R.; Howarth, R.B.; Borsuk, M.E. Pro-environmental behavior. Ann. N.Y. Acad. Sci. 2010, 1185, 211-224. [CrossRef] [PubMed]

56. Bergman, B.G. Assessing impacts of locally designed environmental education projects on students' environmental attitudes, awareness, and intention to act. Environ. Educ. Res. 2016, 22, 480-503. [CrossRef]

57. Gifford, R.; Nilsson, A. Personal and social factors that influence pro-environmental concern and behaviour: A review. Int. J. Psychol. 2014, 49, 141-157. [CrossRef] [PubMed]

(C) 2017 by the authors. Licensee MDPI, Basel, Switzerland. This article is an open access article distributed under the terms and conditions of the Creative Commons Attribution (CC BY) license (http://creativecommons.org/licenses/by/4.0/). 